\title{
A Study of Parasitic Copepod Infesting Two Freshwater Fish Populations (Cyprinus carpio and Abramis brama) from Beni-Haroun Dam (Mila) North-East of Algeria
}

\author{
Houda Berrouk ${ }^{1^{*}}$, Mounia Tolba ${ }^{2}$, Moundji Touarfia ${ }^{1}$ and Chahinez Boualleg ${ }^{1}$ \\ ${ }^{1}$ Laboratory of Terrestrial and Aquatic Ecosystems, Faculty of Sciences, Mohamed Cherif Messaadia \\ University, Souk Ahras, Algeria. \\ ${ }^{2}$ Laboratory of Plant Biomolecules and Plant Improvement, Faculty of Sciences, Larbi Ben M'hidi \\ University, Oum El Bouaghi, Algeria.
}

Authors' contributions

This work was carried out in collaboration among all authors. The results of the article are part of author HB doctoral thesis. Author HB wrote her article from introduction to conclusion. Author MT participated in practical work in the laboratory and realization of the map and the statistical analysis.

Author CB director of thesis, she participated in the revision of this article. All authors read and approved the final manuscript.

Article Information

DOI: $10.9734 / A R R B / 2019 / v 34 i 330159$ Editor(s):

(1) Dr. Md. Aminur Rahman, Professor, Department of Fisheries and Marine Bioscience, Faculty of Biological Science and Technology, Jashore University of Science and Technology, Bangladesh.

Reviewers:

(1) Fábio Henrique Portella Corrêa de Oliveira, Universidade Federal Rural de, Brazil. (2) Mohamed EL. Sayed Megahed, Institute of Oceanography and Fisheries (NIOF), Egypt. Complete Peer review History: http://www.sdiarticle4.com/review-history/54068

Original Research Article

Received 04 December 2019

Accepted 08 February 2020

Published 12 February 2020

\section{ABSTRACT}

Copepods are one of the main fish ectoparasites, commonly known among the parasitism world, due either to their special adaptive capacity or to induce stress in aquatic organisms, as well as the parasitism result is overall a physiological rate affecting the survival of host. This study was, therefore, aimed to investigate the ectoparasite copepods, infesting 277 fishes including 135 of Cyprinus carpio (Linnaeus, 1758) and 142 of Abramis brama (Linnaeus, 1758), collected from BeniHaroun dam (Mila, northeast Algeria). The fishes were subjected to some morphometric measurements and gill dissections and the harvested parasites were afterwards stored and identified. The parasitic indices were determined to examine the effect of size, sex, season and 
microhabitat on the parasitic infestation by using $\chi^{2}$ test. The gill examination of individuals of the two host fishes led to harvest 135 copepods, including 127 individuals from Cyprinus carpio belonging to five species (Ergasilus sieboldi, Ergasilus briani, Neoergasilus japonicus, Neoergasilus longispinosis and Lernaea cyprinacae) and 8 individuals from Abramis brama belonging to the two species: Ergasilus sieboldi and Ergasilus briani, and hence Cyprinus carpio is the most infested species than Abramis brama. This study also revealed that the parasitic index values were high in $C$. carpio $(P=53.00 \% ; A=3.7 ; \mathrm{I}=6.93)$ compared to $A$. brama $(P=12,0.5 \%$, $A=0.12, \quad I=1.00$ ) during autumn, since no effect on infestation was noticed during winter. The statistical analysis has revealed the effect of season on parasitic copepod infestation in the two fish species $\left(\chi^{2}\right.$ obs $=30,959>\chi^{2}{ }_{0.05}=7,815$, ddl =3), Since there was no effect due to the microhabitat and sex.

Keywords: Beni-Haroun dam; Cyprinus carpio; Abramis brama; parasitic parameters; copepods.

\section{INTRODUCTION}

The freshwater fishes are of concern, indeed, a one-third of known species would have disappeared or would be strongly threatened. These living beings found in the aquatic environment are subjected to various anthropogenic attack or natural attack, which mainly includes the parasitism exhibiting a very ubiquitous lifestyle where the individual species radically different and could live together in close relationship [1,2]. So far as known, the parasitism provides the benefit of only one species and makes an essential relationship with living organisms generally involves pathogen action, however, a good parasite does not kill its host [3, Bernard, 2014). Hence, they play a crucial role in the ecosystem processes as different as the regulation of free animals, the structuring of ecosystems or the acquisition of new forms of life. Fish ectoparasites are considered one of the most primary parasites represented by copepods often attached to fish gill arches and occupy an important place in parasitism due to their efficient adaptive capacity. Further, some copepod species can thus weaken the fish host and can negatively affect its body weight gain, reproduction and growth [4,5], while other species appeared even as very pathogenic and induced a massive mortality in infested fish populations $[6,7,8,9]$.

Until now, very limited ecological and taxonomic studies investigating the parasites of freshwater fishes were performed in Algeria, among which those performed by Meddor (2009) on the original descriptions of the parasite entities discovered at the first time on freshwater ichthyofauna. Also, other authors have investigated the parasites of freshwater fish, in particular Cyprinidae family in some freshwater sites of northern Algeria including Bounamouca river [10], various water bodies of El-Kala
National Parck (Aoun-Kaid and Chaib, 1994), Isser river (Boukhalfa, 2008), Oubeira lake [11, Mouaissia et al., 2107), various continental hydrosystems of the Aures regions and the northern Sahara [12], Foum El-khonga dam and Aineldalia region of Souk Ahras city (Brahmia, 2017) and Beni-Haroun dam [13,14]. Therefore, this work was devoted to study the parasites of freshwater fishes, and to provide an inventory of copepod parasites infesting two fish populations of Cyprinidae family (Cyprinus carpio and Abramis brama) from Beni-Haroun dam (Mila city, north-east of Algeria), and hence, the study focuses on the evaluation of epidemiological indices of parasites identified as a function of some biotic parameters, like sex, size, season and microhabitat.

\section{MATERIALS AND METHODS}

The study was conducted on freshwater fish of Beni-Haroun dam (Northeast Algeria), having an important hydraulic strategy with $120 \mathrm{~m}$ high and storage capacity of 960 million cubic meters reserve of water, noting also that the dam has started receiving water from August 2003. The dam is located in Mila province with convergence to Rhumel and Endja rivers of northwestern Graram region (northeast, Algeria). Mila province is $40 \mathrm{~km}$ away from Constantine province and feeds several provinces of northeast Algeria (viz., Jijel, Batna, Ouem elbaouaghi, khenchla and Constantine) by drinking water. Beni-Haroun water dam (Fig. 1) is intended to provide drinking water to more than one-quarter millions of citizens and few hectares and farms $[15,16]$.

\subsection{Sampling, Identification and Fish Dissections}

In this study, the used fishes were randomly collected using gillnet (old fishing method also called as "catch fish") and divided into 135 
individuals of $C$. carpio and 142 individuals of $A$. brama (Meddour et al. 2011). The captured fishes were transferred to the Laboratory of Aquatic and Terrestrial Ecosystems of SoukAhras University of Algeria, and then the species identification was performed according to the nomenclature and criteria provided by Fischer et al. [17]. Thereafter, the identified fishes were weighed before being dissected, fish sex was determined, the gill arches were gently detached by two scissors (dorsal and ventral parts) and stored in pillboxes containing $70 \%$ ethanol.

\subsection{Collection and Identification of Parasites}

The collected copepod parasites were immediacy stored in pillboxes containing $5 \%$ formaldehyde, and labelled by the fish name, sampling date and sample number. The identification of the parasite species was focused on the parasite morpho-anatomical features according to a previously reported method [18].

\subsection{Data Treatment Procedure}

We have used the parasitic indices (Prevalence, Intensity and Abundance) proposed by Margolis et al., [19] and Bush et al., [20] in order to describe the levels of parasite loads.

\subsection{Statistical Analysis}

of The independence between parasitic indices and various studied factors including seasons, sexes, size classes and microhabitat were statistically analysed by $\chi^{2}$ test, using Statistica Software, for Microsoft Windows (version 8.0) where $p<0.05$ was considered significant.

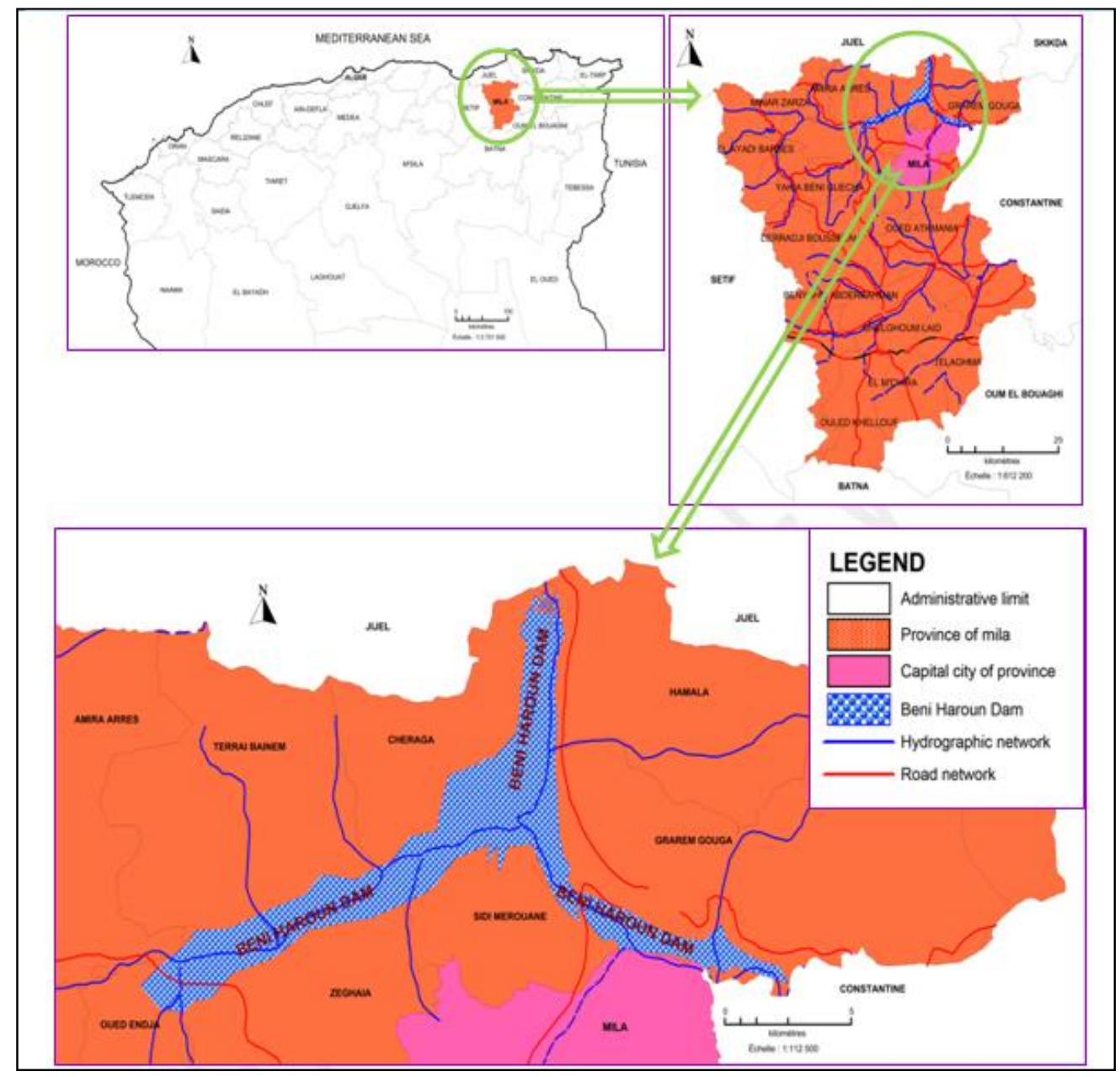

Fig. 1. Map showing the sampling site of Dam Beni-Harroun (Berrouk, 2019) 


\section{RESULTS}

Among the 135 gill fishes of Cyprinus carpio, five species of copepod parasites (Ergasilus sieboldi, Ergasilus briani, Neoergasilus japonicas, Neoergasilus longispinosis and Lernaea cyprinacae) were collected, while only two species (Ergasilus sieboldi and Ergasilus briani) were collected from 142 fishes of Abramis brama.

\subsection{Epidemiological Indices}

\subsubsection{Variations of parasitism is the function on the number of collected copepods in Cyprinus carpio and Abramis brama}

The parasitic indices of the collected copepods in C. carpio showed highest prevalence values in $E$. briani $(P=7.40 \%)$ and $L$. cyprinacea $(P=5.92)$, since the highest values of intensity and mean abundance were noticed in $E$. sieboldi $(I=6.66$; $A=0.26)$, where the collected copepods were recorded $(\mathrm{P}=3.52, \mathrm{l}=1.00, \mathrm{~A}=0.03)$. The $A$. brama revealed the highest values of parasitic indices (Fig. 2).

\subsubsection{Variation of parasitism is the function of seasons}

The highest parasitic indices of five parasitic copepod species collected in C. carpio were observed during autumn $(P=53.33 \% ; A=3.7$ ?; $I=6.93$ ), and the lowest values were noticed in winter ( $P=5.4$ ?, $A=0.05, \mathrm{l}=1 . ? ?)$. Whilst, A. brama revealed high values of prevalence and abundance $(P=12.5 ? \% ; A=0.12)$ in autumn along with the same intensity value during spring and summer, but no parasitic infestation was observed during winter (Fig. 3).

The prevalence values showed the season effect on the parasitic infestation in the two host species of $C$. carpio and $A$. brama ( $\chi^{2}$ obs $=30,959>\chi^{2} 0.05=7,815$; ddl=3)

\subsubsection{Variation of parasitism is the function of host fish sex}

The parasitic indices of $C$. carpio showed the highest values of prevalence in males $(P=26.02 \%)$, since the abundance and intensity were respectively high in females of the same host species $(A=1.06 ; I=5.07)$. However, the species $A$. brama revealed high prevalence and abundance values in females $(P=9,09 ; A=0,09)$, but the intensity was found to be the same in both sexes of the same host species (I=1.??) (Fig. 4). Both fish sexes appeared to have no effect on the parasitic copepod infestation in the two host species $\left(\chi^{2}\right.$ obs $=2.451<0.05=\chi^{2} \quad 0.05$ $3.841 ; \mathrm{ddl}=1$ ).

\subsubsection{Variation of parasitism is the function of fish host size}

The parasitic indices of copepods identified from different size classes of $C$. carpio showed that specimens of sizes higher than $40 \mathrm{~cm}$ exhibit the highest prevalence levels $(P=100 \%)$. Regarding the abundance and intensity, the highest values

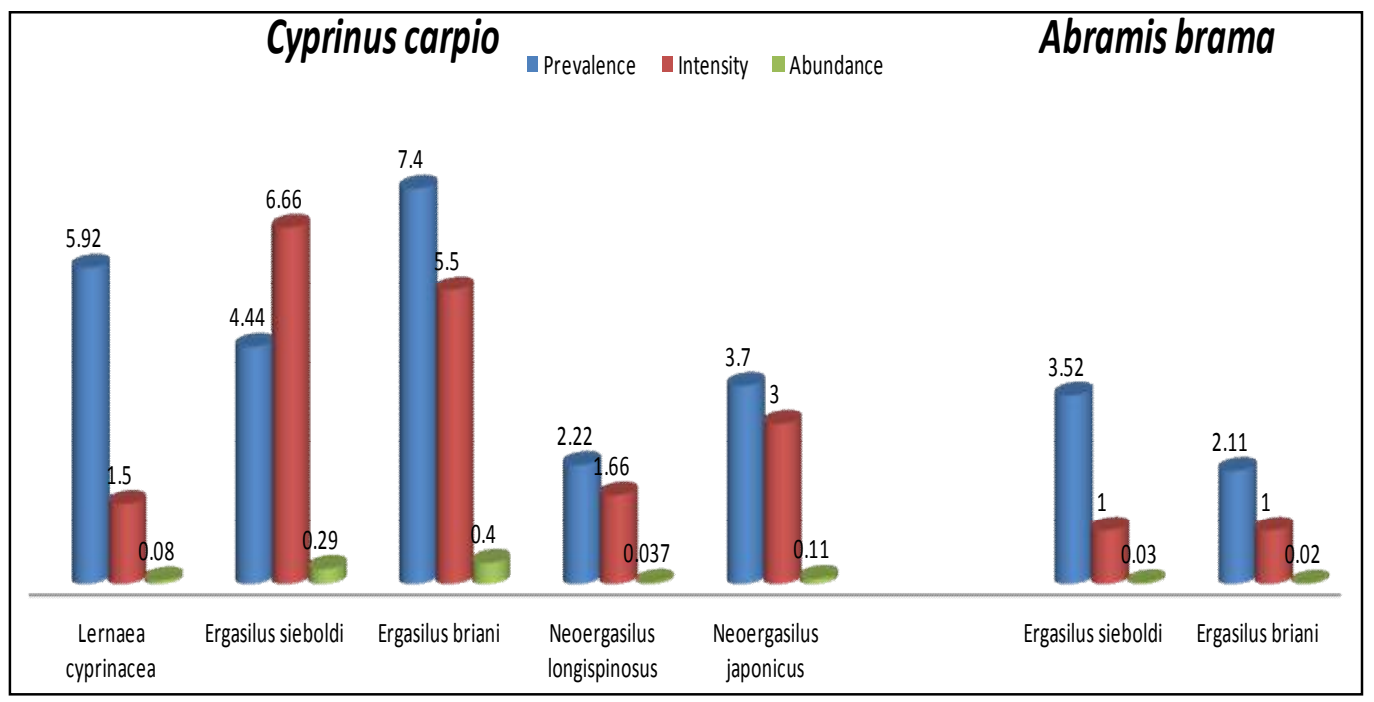

Fig. 2. Distribution of prevalence (P\%), Intensity (I) and Abundance (A) of the collected copepods in two host species of Cyprinus carpio and Abramis brama 
were noticed in the specimens of size class of $35-40 \mathrm{~cm}$, where $A=2 . ?$ ? and $I=9.37$. On top of that, the parasitic indices of copepods identified in various classes of $A$. brama showed that the specimens of the small size of $15-20 \mathrm{~cm}$ exhibit the highest values of prevalence $(P=33.33 \%)$, while the abundance and intensity were found to be equal or nearly the same (Fig. 5).

\subsubsection{Variation of parasitism is the function of micro-habitat}

The distribution of the parasitic indices of copepods collected from the two gill arches of $C$. carpio showed a slight increase in the prevalence $(P=12.59 \%)$ in the left gill, but the abundance and intensity were slightly increased in the right gill $(A=0.48 ; 1=4.44)$. Likewise, a slight increase was noticed in the prevalence and abundance in the right gill arches $(P=3.52 ; A=0.03)$, since the intensity was found as the same in both gill arches (I=1.??) (Fig. 6).

However, the prevalence did not differ in the two gill arches (left and right gills) of both the studied species $\left(\chi^{2}\right.$ obs $\left.=0.44<\chi^{2} \quad 0.05=3.841, \mathrm{ddl}=1\right)$, which statistically explained that the microhabitat had no effect on the parasitic copepod infestations.

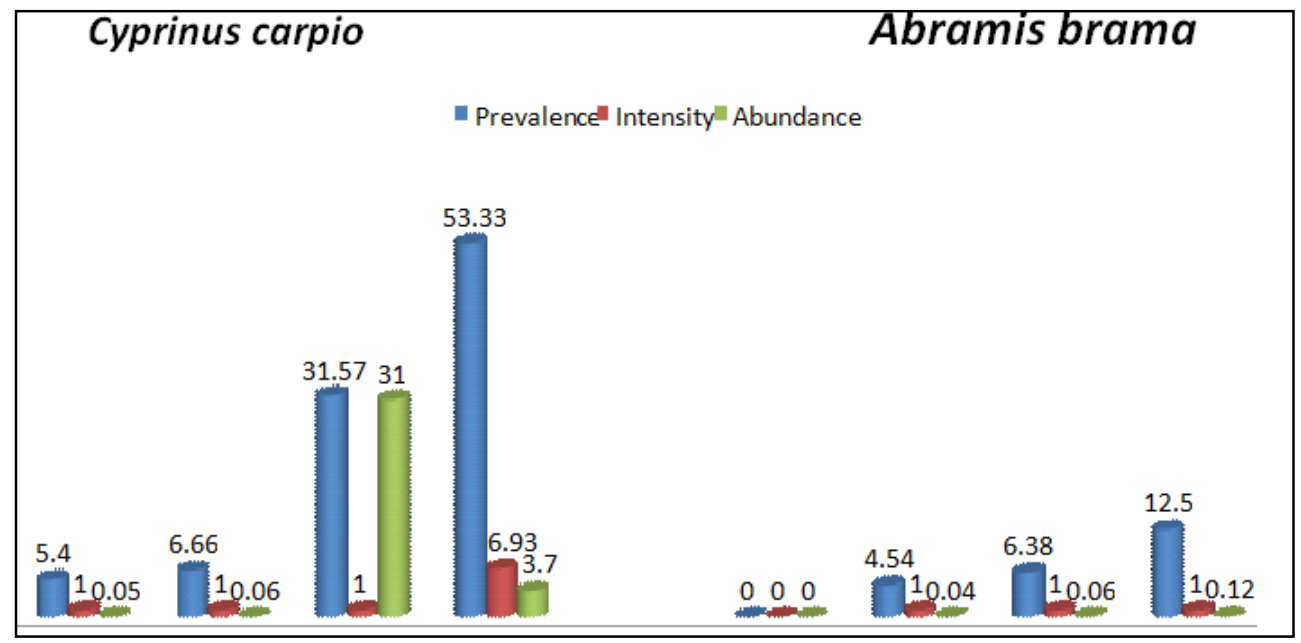

Fig. 3. Seasonal variation of prevalence (P\%), Intensity (I) and abundance (A) in two host species of Cyprinus carpio and Abramis brama

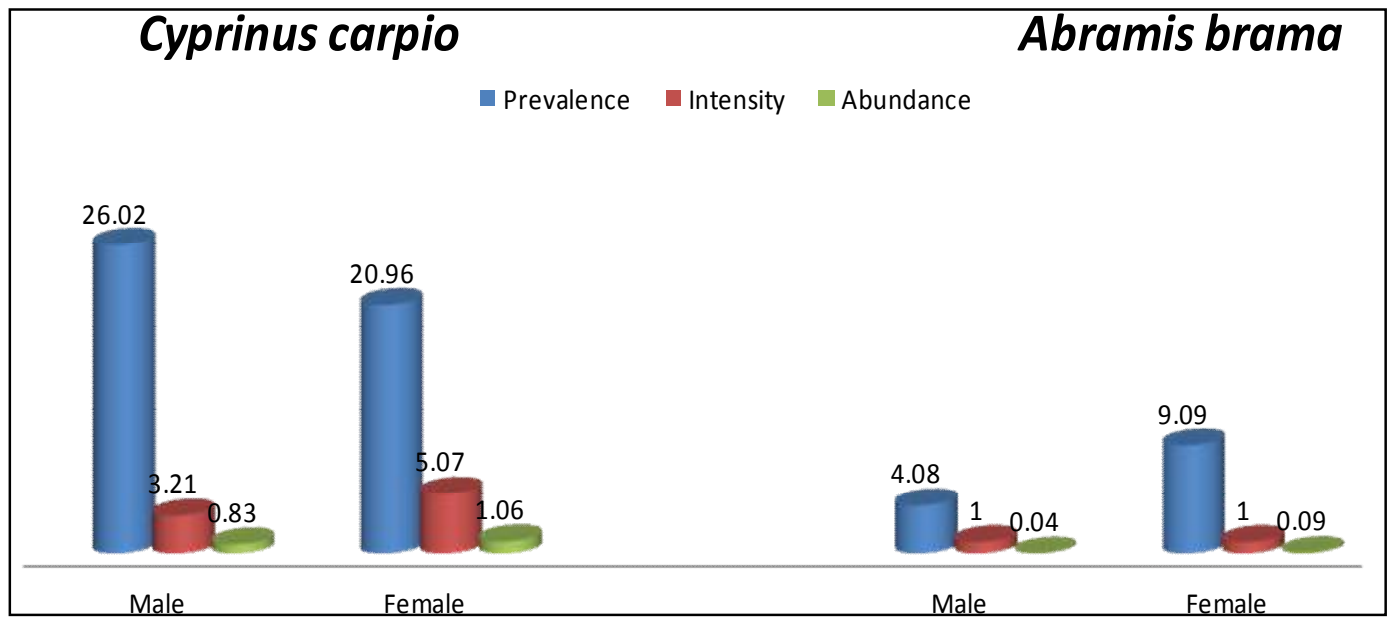

Fig. 4. Distribution of prevalence ( $P \%)$, Intensity $(I)$ and Abundance $(A)$ of parasitic copepods is the function of sex in two host species of Cyprinus carpio and Abramis brama 


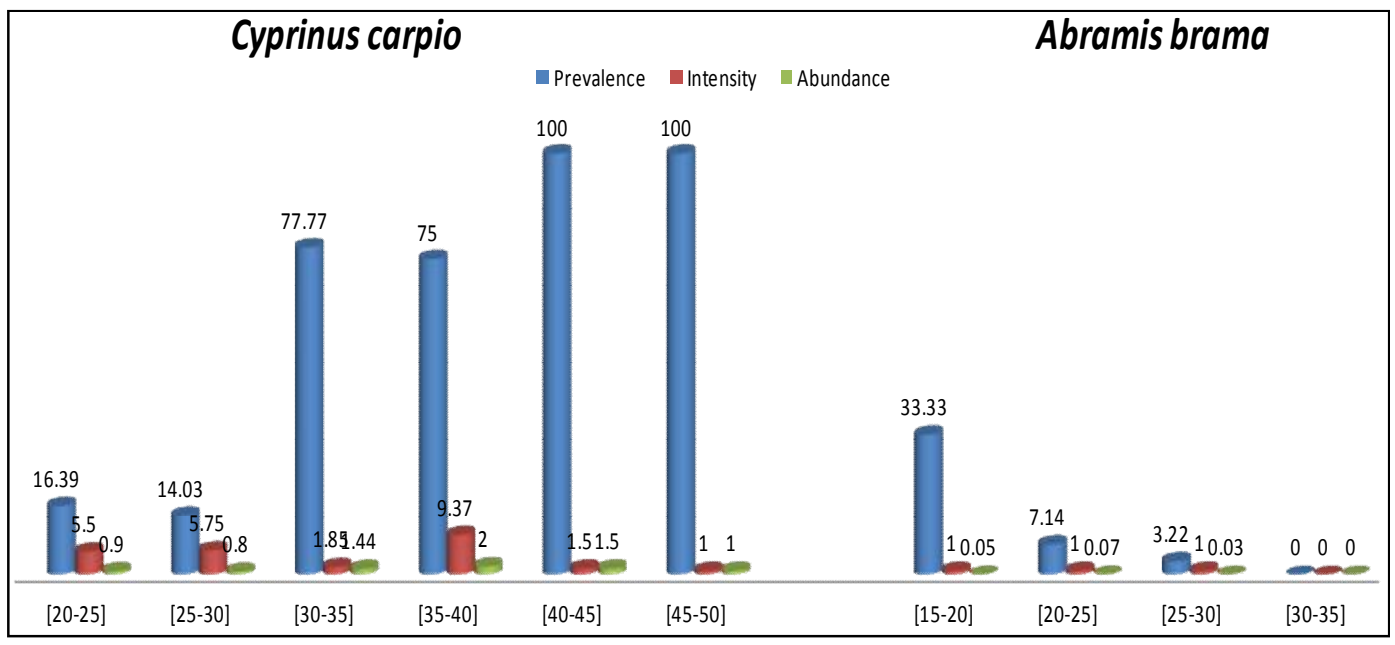

Fig. 5. Distribution of prevalence (P\%), Intensity (I) and Abundance (A) of the collected copepods is the function the size classes in two host species of Cyprinus carpio and Abramis brama

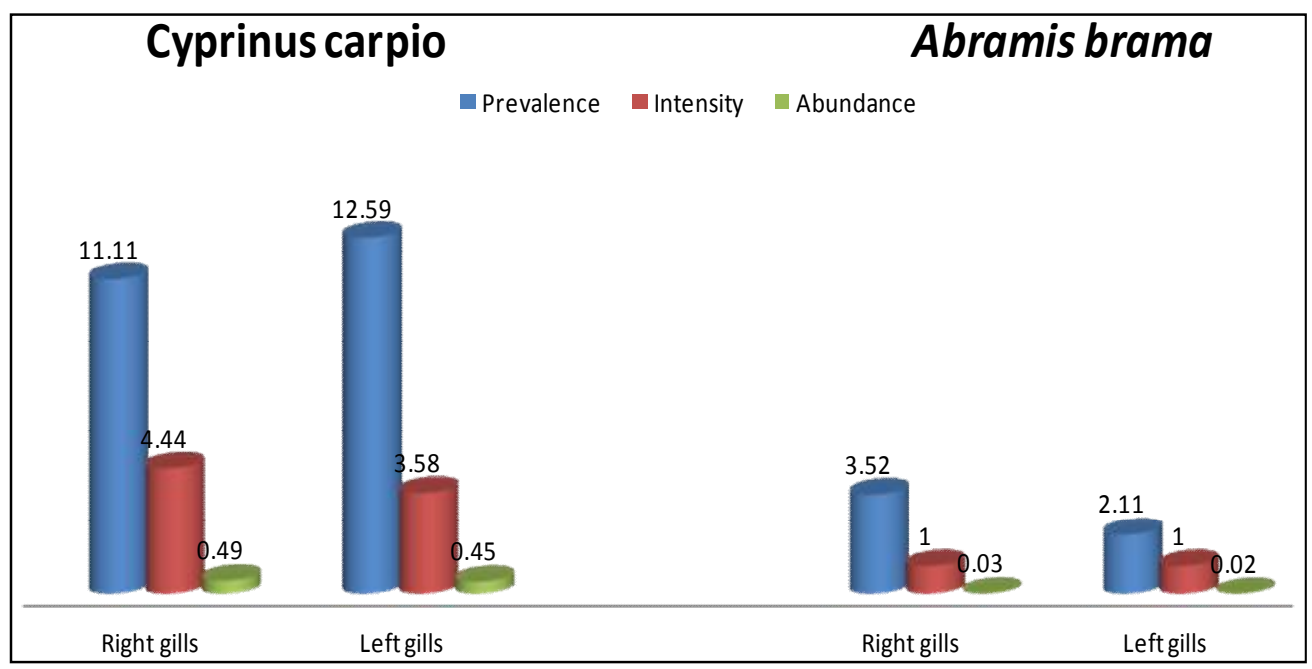

Fig. 6. Distribution of prevalence (P\%), Intensity (I) and Abundance $(A)$ in two gills of the two host species of Cyprinus carpio and Abramis brama

\section{DISCUSSION}

The findings of the present study revealed a very weak parasitic infestation in Beni-Haroun dam, where the examination of 135 individuals of Cyprinus carpio and 142 individuals of Abramis brama promoted us to collect 127 individual parasites in carp and 8 individual parasites in bream, thus suggesting that $C$. carpio sheltered parasites 15 times more than $A$. brama species. The study also showed the existence of inequality in parasitism against both host species. In this regard, other study conducted on Obeira Lake had proved that Luciobarbus callensus can shelter a number of parasites 11 times more than C. carpio (Brahmia, 1995), and according to Combes [21], this variation could be resulted from genetic factors, the age of host and even the presence of other parasites. The morphometric features of the inventoried parasites of the gill arches of the two species lead to identify five species, among which three parasite species (Neoergasilus japonicus, Neoergasilus longispinosis and Lernaea cyprinacea ) were found in C. carpio, since the two other ones (E. briani and $E$. sieboldin) are common in the two host species. Furthermore, the parasitic indices of the collected copepods 
were variably distributed in the two host species, and the highest prevalence values in $C$. carpio were noticed by $E$. briani and Lcyprinacea. In addition to that, the highest parasitic loads were evidenced by $E$. sieboldin, but the index in $A$. brama species was presented by $E$. sieboldin, exhibiting the highest prevalence and parasitic loads. Thus, parasite infestations in various aquatic organisms have been well-documented in many works including those performed in lake Balatonen (Bulgary) showing E. sieboldi as a parasite species on the gill of $C$. carpio, $A$. brama and Carassus carassus [22], the parasite species L. cyprinacea and Ergasilus sp. were found in Luciobarbus callensus and C. carpio in Bounamoussa river and Oubeira lake [10], and also Chaibi [11] reported that the parasite Ergasilus sp. was found in $L$. callensus in Timgad dam (Batna city, North-eastern Algeria) and Lernaea cyprinacea in Ghardia (South Algeria) river. Further, Reza et al. [23] had reported the presence of $L$. cyprinacea as a parasite species on the gills of $C$. carpio in Iran region, and Boucenna [12] found the parasite L. cyprinacea in the gill of $C$. carpio and $L$. callensus in Foum Elkounga and Ain Eldalia dams, and the parasites Neoergasilus japonicus and Neoergasilus longispinosis in the gills of $L$. callensus , C. carpio and C. carassus, as well as no parasitic infestation was noticed in $A$. brama in the same zones and periods of study. Mokliayer (1981) and Jalali [24] had identified $L$. cyprinacea as the most harmful species in Cyprinidae family. Moreover, Piasecki et al. [9] confirmed that $E$. sieboldi has no specificity on the host and thus, it can infest the majority of freshwater fishes and cause a major parasitic disease for the worldwide aquaculture. In contrast, Euzet and Combe [25] have criticized this study by the reason of using only one host, although the parasite using many hosts are known as generalist parasite, and according to Kitahara and Fuji [26], the concepts "generalist and specialist" are relatives. Noteworthy, the evaluation of the parasitic indices revealed that the five collected copepod species from the two host species show variation as a function of seasons, i.e the infestation rate and parasitic loads are highly increased in the species $C$. carpio A. brama during autumn along with no parasitic infestation during winter. This variation is likely due to the increased temperature even during the autumn period, after its elevation during summer. Boualleg et al. [27] reported that the isopod Gnathia sp. markedly infests its hosts during autumn and summer, and Aliniaeema et al. (2015) reported that the prevalence and intensity of copepods infesting C. carpio, C. Auratus and six other host fishes are highly increased during autumn and summer in three sites of El-basrah (Iraq). Additionally, Boucenna [12] had shown that the monthly collected crustacean from gills of $C$. carpio and $L$. callensus from Foum-Elkhonga dam revealed the highest infestation levels during autumn and then during summer, meanwhile the highest parasitic loads were observed during winter in males of $L$. callensus. A study conducted in Finland on Ergasilidae copepods did not reveal a regular seasonal phenomenon, indicating subsequently that $N$. japonicus could breed or recruit on the fish hosts not only due to a higher temperature but also to a lower temperature in autumn and winter [28]. Benmansour [29] reported the crucial role of seasons in the development and the abundance of copepod parasites, as well as the temperature, was found to be one of the main factors acting in the seasonal fluctuations of parasite populations, and here Koskivaara et al. [30] proved that water temperature change is generally considered as one of the highly important factors determining the presence and abundance of parasites. Regarding the variation of parasitism as a function of sex, the parasitic indices were highly increased in females of $C$. carpio and A. brama, but no significant difference in the prevalence of the collected copepods was observed between fish sexes, thus indicating that both sexes are equally infested. Some authors have reported the effect of sex on parasitic infestation, and among them, Koyun et al. [31] showed no sex effect on parasitic infestation of Paraergasilus longidigitus in $A$. alburnus species in Enne Dam (Turkey). Ramadane [32] indicated from eastern Algeria that just Argulus $s p$ appeared a preference on female hosts. Allalgua et al., [33] had found no effect of sex of C. carpio infested by monogen parasites from Foum- ElKhanga dam, and Boucenna [12] have reported that females of $C$. carpio are highly affected than males, however, males of $L$. Callensus are the most infested and no significant difference in the prevalence and intensities of the collected copepods was noticed between fish sexes. Conversely, Abdelhusein [34] found that the prevalence of Ergasilus sp. is affected by sexes of $C$. carpio and $O$. niloticus, and similarly, Anvarifar et al. [35] found significant differences in copepod Tracheliastes polycolpus infestation between both sexes of Capoeta gracilis. Therefore, the parasitic copepods infesting fish hosts do not choose between fish sexes. On the other hand, the distribution of parasitic indices of gill 
ectoparasites as a function of host fish sizes had shown that in C. carpio, the fishes of high size ranging from 45 to 50 are highly infested, and this is in line with the work conducted in the same study zone by Berrouk et al. [14]. Further, Morand et al. [36] found a positive relation between host sizes of 36 marine fish species and the ectoparasite infestation in the case when data are phylogenetically controlled. Moreover, the work of Brahmia (2017) conducted on Oubeira Lake had indicated that the monogen Dactylogyrus anchoratus infests the big sized carps as compared to those of small size, and the copepod, Argulus foliaceus infests the specimens of big sized carps, while the work of Tolba et al, [13] conducted on Beni-Haroun dam revealed that the nematodes never infest the small individuals of Luciobarbus callensus and the cestodes infest the individuals whose sizes are ranging between 30 and 35 . What's more, Winermiller et Rose [37] had reported that big sized hosts are overall, those surviving longer and so they become susceptible to be exposed during long period to infestation by new parasite species. Accordingly, Zelmer and Arai [38] found that the older poles and the big size hosts have a tendency to host a large number of parasite species and greater parasitic infra-communities, and Sasal et al. [39] suggested that the big sized hosts are susceptible to offer a large number of niches to parasites and likely have been exposed during long period. Furthermore, Zapata et al. [40] had mentioned that the biggest fishes could have more different parasite species compared to those of small size. As previously reported $[41,42,43,44]$, the big sized fishes have great gill surface to host many parasites. But, Ramadane (2010) indicated that the identified ectoparasites of the teleost fishes in eastern Algeria infest the specimens of different size classes. Furthermore, the distribution of the parasitic indices of the collected copepods in gills of $C$. carpio revealed that the left gills were found to be highly infested as compared to right gills, and inversely in $A$. brama, showing that the right gills are the most infested. In parallel, the work of Boualleg [45] conducted on three species of the genus Pagellus in eastern coast of Algeria had revealed that left gills are the most infested than the right ones. Meanwhile Boucenna et al. [46] had shown from Foum El-Khonga dam that the infestation affects equally the aches of the two gills (right and left gills) in C. carpion, and this author in 2017 found in the same study zone that the infestation level in $L$. callensus by copepod parasites were found to be almost equal in both gills, and from Ain Eldalia dam (North-eastern
Algeria), the author had found the highest level of parasitic infestation and loads in the right gills of C. carpio.

\section{CONCLUSION}

The examination of 277 fishes belonging to two species (C. carpio and A. brama) in Beni-Haroun dam (Mila, Algeria) promoted us to collect 135 parasites, including 127 copepods in C. carpio attached to five species, namely $E$.sieboldi, $E$. briani, $N$. japonicus $N$. longispinosis and $L$. cyprinacae, and eight copepods in A. brama attached to two species: E. sieboldi and E. briani.

Conclusively, the present study highlighted the following points:

- The two studied host species were not equal against parasitism.

- Cyprinus carpio was the most infested species by copepod parasites.

- The copepod parasites infested the two host species during autumn period.

- The parasitic infestation was low or absent during winter period.

- The specimens of the big and medium sizes were the most infested in the two host species.

- The sex and microhabitat revealed no effect on the parasitic infestation in the two host species.

Consequently, it seemed worthwhile to develop the following points:

- Extend such a study on other fresh water surfaces, like dam, lakes and even rivers in the Algerian territory.

- Display such a study to other teleost fishes of several other families to search for their parasitic copepods.

- Remove the sampling effort that can show the importance in estimating the specific parasitic richness.

- Study the pathogenic effect of the identified copepod parasites and to evaluate its effect on the growth and development of host fishes.

- Evaluation of the impact of certain parameters (temperature, salinity, $\mathrm{pH}$ and pollution) on parasite diversity.

\section{ACKNOWLEDGEMENTS}

The researchers warmly thank the fishermen of Beni -Haroun dam fortheir help in getting fish 
samples. They also thank $\operatorname{Dr}$ Berrouk Abdallah sofiane (University Khalifa. Abu- Dhabi, United Arab Emirates, for this invaluable advice and immense help.

\section{COMPETING INTERESTS}

Authors have declared that no competing interests exist.

\section{REFERENCES}

1. Combes C. Parasitism. The Ecology and evolution of Intimate Interactions. The University of Chicago Press, Ltd, London. $2001 ; 701$.

2. Fillippi J. Parasitologic study of Anguilla Anguilla in two lagoon of Corse and Ultrastructural stady of tegument of three parasitic digenes parasites of Anguille. These de Doctoral Thesis, University of Corse. 2013;212.

3. Cassier P, Brugerolle G, Combes C. Dynamic parasitic balance. Masson Paris. 1988;361.

4. Kabata Z. Lernaeocera obtuse. Its biology and its effect on the haddock. Marine Research, Department of Agriculture and Fisheries for Scotland. 1958;(3):1-26.

5. Dekinkelin P, Michael C, Ghittino P. Precis of fish pathology institute of agronomic research. Office International Office of Epizootils. 1985;348.

6. Hewitt GC. Tow species of Caligus (Copepoda: Caligidae) from Australian water, with a description of some developmental stages. Pac. Sci. 1971;25: 145-164.

7. Lin CL, Ho JS, Chen SN. Two species of Caligus (Copepoda: Caligidae) parasitic on black sea bream (Acanthopagrus schlegeli) cultured in Taiwan. Fish Pathol. 1994;29:253.

8. Ho JS. The major problem of cage aquaculture in Asia relating to sea lice. In: Liao IC, Lin CK Lin (Eds). Proceedings of the I st International Symposium on cage Aquaculture in Asia: 2-6 Nov. 1999, Tungkang, Manila: Asian Fisheries Society and Bangkok: World Aquaculture SocietySoutheast Asian Chapter. 2000;13-19.

9. Piasecki W, Goodin AE, Eiras JC, Nowak BF. Importance of copepod in Freshwater aquaculture. Zoological Studies. 2004; 43(2):193-205.

10. Meddour A. Fish farming and biodiversity of fish parasitofauna in North-east of Algeria Doctoral Thesis, Option Sciences
Vétérinaires, University of El Taref, (Algeria). 2009;23.

11. Chaibi R. Knowledge of the continental water ichthyfaune of the water region and the Northern Sahra with its enhancement. Doctoral thesis, Biology option, University Mohamed Khider, Biskra, (Algeria). 2014; 237.

12. Boucenna I. Study of the parasitic crustaceans of the ichthyofauna of freshwater ecosystems of the region of Souk-Ahras, Doctoral Thesis, University Chadli Benjdid, El Taref, (Algeria). 2017; 149.

13. Tolba M, Kaouachi N, Boualleg C, Mouaissia W, Allalga A, Berrouk $\mathrm{H}$, Boulahbal S. Impact of parasitic Helminths on the Growth of Luciobarbus callensis populating Béni Haroun dam (East of Algeria). World Journal of Environmental Biosciences. 2018;1(7):92-99.

14. Berrouk H, Tolba M, Boucenna I, Touarfia M, Bensouilah M, Kaouachi N, Bouallag C. Copepod parasites of gills of Luciobarbus callensis (Valencienne, 1842) and Carassuis carassuis (Linnaeus, 1758) (Cyprinid fish) collected from Beni Haroun Dam (Mila, Algeria). World Journal of Environmental Biosciences. 2018;7(4):1-7.

15. Mebarki A. Hydrology of the basins of eastern Algeria, Water resources, planning and environment. Doctoral Thesis. University Mentouri Constantine, (Algeria). 2005;360.

16. Mouaissia W. Contribution à l'étude de la biologie (Croissance, structure morphometrique, reproduction et régime alimentaire) de l'espèce Barbus callensis (Cyprinidés) dans le barrage de BéniHaroun Mila-Algérie-.Thèse de Doctorat 3 eme Cycle. Université Mohamed El chérif Messaadia, Souk-Ahras, (Algérie). 2017; 153.

17. Fischer, Schneider M, Bauchot ML. Sheets of FAO of species identification for the nneds of Mesiterranean fishing and the black sea (Fishing area 37), Revision 1, The vertebrates. Organization of the united nations for food and agriculture, Rome. 1987;2:763-1579.

18. Yamaguti S. Parasitic copepod and branchiura of fish (Teleosteen) Tome I: Tome II: Plates. 1992;1963:1059.

19. Margolis L, Esch GW, Holmes JM, Karis AM, Schad GA. The use of ecological terms in parasitology (rapport an ad hoc committee of the American Society of 
parasitologists). Journal of Parasitology. 1982;(68):131-133.

20. Bush AO, Lafferty KD, Lotzjem ET, Shostak AW. Parasitology meets ecology on it sownterms in: Margolis et al. Revisited. Journal of Parasitology. 1997; (83):575-583.

21. Combes. Sustainable interaction ecology and evolution of parasitism. Masson, Paris, collection ecology n 26, Paris. 1995;524.

22. Molnar K, Szekely CS. Mysobolus infesction of the gills of common bream Abramis brama $\mathrm{L}$ in Lake balton and in the Kis-Balton reservoir, Hungary, Acta Veterinaria Hungarica. 1999;47(4):419-4.

23. Reza SL, Mohsen F, Houshang J, Nahid $\mathrm{S}$, Hossein KJ, Mohammad F. Infection rate of common carp (Cyprinus carpio) to Lernaea cyprinacea parasite in Warm Season of year in Farming Ponds of Shushtar in Khusestan Province. Biomedical and Pharmacology Journal. 2014;7(1):33-339.

24. Jalali B. Parasites and parasitic diseases of fresh water of Iran (In Persian). Iranian Fisheries. 1998;564.

25. Euzet L, Combes C. Problems of the species in parasitic animals. In problems of the species in the animal kingdom. Bulletin of the Zoological Society of French. 1980; (40):239-28.

26. Kitahara M, Fujii. Biodiversity and community structure of temperate butterfly species within a gradient of human disturbance an analysis based on the concept og generalist vs. specialist strategies. Researches on Populations Ecology. 1994;36:187-199.

27. Boualleg C, Kaouachi N, Bensouillah M. The infestation of 12 Sparid species by the parasite Gnathia $\mathrm{sp}$ in the east Algerian coast. Bulletin of Scientific Institute Rabat. 2012;34(1):65-70.

28. Tuuha E, Valtonen ET, Taskinen J. Ergasilid copepods as parasites of perch and roach in Central Finland; seasonality, maturity and environmental influence. $\mathrm{J}$ Zoo. 1992;228(3):405-422.

29. Benmansour B. Biodiversity and bioecology of parasitic copepods of Teleosteens fish copepods. Doctoral Thesis. University of Tunisia, EIManar. 2001;454.

30. Koskivaara M, Valtonen ET et Prost M. Seasonal occurrence of Gyrodactylid Monogeneans on the roach (Rutilus rutilus) and variations between four Lakes of differing water quality in finland. Aqua Fenn. 1991;21(1):47-55.

31. Koyun M, Altunel FN. Metazoon parasites of bleak (Alburnus alburnus) crucian carp Carassuis carassuis and golden carp (Carassuis auratus) in Enne Dam lake. Turkey. In. J Zool. Res. 2007;1: 2,1-7.

32. Ramadane $Z$ Identification et écologie des ectoparasites crustacés des poissons Téléostéens de la cote Est Algérien. Thèse de Doctorat, Université Badji-Mokhtar, Annaba, (Algérie). 2009;235.

33. Allalgua A, Guerfi S, Kaouachi N, Bouallag C, Boucenna I, Barour C , Menasria A, Bensouilah M. L'infestation de Cyprinus carpio (Cyprinidés) peuplant le barrage Foum El-khenga (Souk-Ahras, Algérie) par les monogènes parasites. Bulletin de la Société Zoologique du France. 2015;140(3):217-232.

34. Abdelhusein JAH, Ramteke PW. Investigations on parasitic diseases in fish ofriver, Yamuna during the summer season. Europ Academic Research. 2014; 2(8):10057-10097.

35. Anvarifar $H$, Mousavi-Sabet $H$, Satari $M$, Vatandoust S, Khiabani A. Occurrence intensity of Tracheliastes polycoplus on Capoeta capoeta grasilus in Tajan River from the Southeast of the Caspian Sea. European Journal of Zoological Research. 2014;3(2):103-107.

36. Morand S, Poulin R, Rhode K, Hayward C. Aggregation and species coexistence of éctoparasites of marine fishes. International Journal of Parasitology. 1999; (29):663-672.

37. Winemilleer OK, Rose AK. Patterns of lifehistory diversification in Norh American fishes implications for population regulation. Can. J. Fish. Aqua. Sci. 1992; 49:2196-2218.

38. Zelmer DA, Arai HP. The contributions of host age and size to aggregated distribution of parasites in Yellow perch, Perca flavescens, from Garner Lake, Alberta, Canada. The Journal Parasitol. 1998;24-8.

39. Sasal P, Morand S et, Guegan JF. Determinants of parasite species richness in Mediterranean marine fishes. Marine Ecology Progress.1997;Series: 149,61-71.

40. Zapata A, Diez B, Cejalvo T, Gutirez C, Defrias et Corts A. Ontogeny of the 
immune system of Fish. Fish shellfish Immunol. 2006;20:126-136.

41. Guegan JF, Hugueny B. A nested parasite species subset pattern in tropical fish: Host as a major determinant of parasite infracommunity structure. Oecologia. 1994; 100:184-189.

42. Bilong-Bilong CF. The parasitic monogenes of cameroun fresfwater fish: Biodiversity and specificity; biology of infested populationsdes by Hemichromis fasciatus. Doctoral Thesis, University of Yaoundi. Faculty of Sciences, (Cameroun). 1995;341.

43. Bakke TA, Harris PD, Cabl J. Host specificity dynamics: Observations on gyrodactylid monogeneans. Inter. J. Parasitol. 2002;32:281-308,3-107.
44. Cable J, Tinile YRC et, Harris PD. Survival and embryo-development of Gyrodactylus gasterostei (Monogenea: Gyrodactylidae) J. Parasitol. 2002;124:53 68.

45. Boualleg $C$, Seridi M, Kaouachi N, Quiliquini Y, Bensouillah M. The parasitic copepods of Teleosteen fish from the eastern Algerian coast, Bulletin of Scientific Institute, Rabat. 2010;32(2): 65-7.

46. Boucenna I, Boualleg C, Kaouachi N, Allalgua A, Menasria A, Maazi MC, Barour C, Bensouilah M. Infestation of population Cyprinus carpio with parasitic copepods in Foum El Khanga Dam (Souk-Ahras, Algeria). Bulletin of Society Zoologic France. 2015;140(3):163-17.

(c) 2019 Berrouk et al.; This is an Open Access article distributed under the terms of the Creative Commons Attribution License (http://creativecommons.org/licenses/by/4.0), which permits unrestricted use, distribution, and reproduction in any medium, provided the original work is properly cited.

Peer-review history:

The peer review history for this paper can be accessed here: http://www.sdiarticle4.com/review-history/54068 